\title{
The determination of phenazone in blood plasma for obtained sistem suitable test of monitoring drug level
}

\author{
Mochamad Lazuardi \\ Veterinary Pharmacy Subdivision, Veterinary Basic Science \\ Veterinary Faculty, Airlangga University \\ Surabaya - Indonesia
}

\begin{abstract}
The determining of Phenazone to human blood plasma from healthy man after separated by solid phase extraction (SPE) and spectroscopic measurements has been investigated. The objective of that research was to obtain system suitable test for determine the Phenazone level in biological fluids (human blood plasma), for new performed dosage regimented in clinical dentistry. The method can be divided into the following four steps. 1. Centrifugation the blood sample, 2. Extraction from blood plasma and, 3. Separation by SPE with manual pressured, 4. Elution to SPE followed by the measurement on a spectrophotometer in the ultra violet region. The critical value of $|\mathrm{t}|$ at the $5 \%$ confidence level indicates that there is no systematic error in the linearity proposed method. Recoveries for this research were obtained at ranging 93.460 to $95.598 \%$. The coefficient variation precision of this procedure was clearly good at smallest than $2 \%$. The analytical procedure can be carried out in one working operation as a monitored therapeutic activity.
\end{abstract}

Key words: phenazone, solid phase extraction, spectrophotometer UV-Vis

Correspondence: Mochamad Lazuardi, c/o: Veterinary Faculty, Airlangga University. Jln. Mulyorejo (Kampus C) Universitas Airlangga Surabaya, 60115. E-mail: ardiunair@ hotmail.com

\section{INTRODUCTION}

Phenazone (as an analgesic and antipyretic properties) has been given by mouth. ${ }^{1}$ Topically, solution containing 5 $\%$ of Phenazone have been used locally as ulcers drops in disorders such as acute gingivitis. ${ }^{2}$ The dentist was usually approved with that dosage form as an analgesic and antiinflammatory agent. In clinical cases, the re-arrangement of regimentation dosage of Phenazone for treated pediatrics patient was usually problems. Those problems were appeared after showed that Phenazone at long period's usage can be induced Reye syndrome of red blood cell. That problem would be reduced if the dentistry were using re-designing dosage form concepts by monitored drug level during the therapeutic periods of pediatric patients for obtained satisfaction dosage form. For obtained a suitable drug levels, the method of drug level determination was usually researching. During recent years several papers have been published on the Phenazone. ${ }^{3-7}$ However, the results obtained are often in poor agreement. The accuracy and the precision of the analytical method used may give the contribution on the variation of the result. The new method of Nuraini et al., ${ }^{8}$ was reported that recoveries was obtained at ranging 86.010 to $88.069 \%$ and their coefficient variation of precision at ranging 0.433 to $3.871 \%$. The recovery of new method at above was not satisfaction yet, although their precision was nearly exactly. Therefore, the purpose of this work was to develop an accurate method for the determination of Phenazone in human blood plasma using fourth-step sample preparation method.

\section{MATERIAL AND METHODS}

The analytical method used in the present work incorporates a partition-adsorption of drug-biological matrix separation concepts. ${ }^{9}$ The separation apparatus of that equipment was used Solid Phase Extraction ODS ($\mathrm{CH}_{17}-\mathrm{CH}_{3}$ ) reverse phase at $3 \mathrm{ml}$ capacity (Sigma Chem. Corp.,). Plastic pestil of $3 \mathrm{ml}$ SPE ODS-C18 was used as a manual mobile phase pressure. A pure Phenazone from Sigma Corp. Chem., was used as reference drug material. The Spectronic Hitachi 1100 UV-Vis was used as a measurement drug concentration. The healthy human blood plasma (Indonesian man) was used as an artificial human blood plasma. The human blood plasma was obtained from Indonesia Red Cross Unit. The research protocol was used four step procedures as follows; the $1^{\text {st }}$ step was analyzed linearity of Phenazone in distillated water from stock solution. The standard stock solutions were made up as $1000 \mu \mathrm{g} . \mathrm{ml}^{-1}$ from $100 \mathrm{mg}$ of Phenazone pure. The standard solutions of 0.5 to $100 \mu \mathrm{g} \cdot \mathrm{ml}^{-1}$ were prepared by sequential dilution of the standard stock solution. Both standard and stock solutions were placed in test tube. The linearity was analysis during two hours from 0.5 to 100 $\mu \mathrm{g} . \mathrm{ml}^{-1}$ of the standard solution vs. absorbance $(\AA)$ on 230 $\mathrm{nm}$ at five times replications. The result data of the step one on graphic illustration of the concentration solution series vs. absorbance unit full scale (AUF) will be used as an additional standard solution data. ${ }^{10}$ The $2^{\text {nd }}$ step was produced artificial samples in human blood plasma. The pure of Phenazone were weighing of $100 \mathrm{mg}$ and dissolved 
with human blood plasma to produce samples stock at 1000 $\mathrm{ppm}$. The stock samples were prepared at ranging series additional standard concentration of $0.5-100 \mathrm{ppm} .{ }^{10-12}$ The $3^{\text {rd }}$ step was prepared artificial sample. The samples were extracted by SPE as described Akira et al., ${ }^{13}$ and Nuraini et al. ${ }^{8}$ as follows; one ml plasma samples were added $1 \mathrm{ml}$ chloroform and shake up well at 10 minutes. Their solutions were added $2 \mathrm{ml}$ with distillated water and centrifuge 3000 rpm (15 minutes). The supernatant were removed sample vials and keep on dark room about 5 minutes. The SPE were activated with inserting $1 \mathrm{ml}$ methanol and $1 \mathrm{ml}$ distillated water consists of $5 \%$ glacial acetic acid. The supernatant were inserted to SPE and vacuum drying the SPE at about 30 minutes. The SPE were added with $3 \mathrm{ml}$ elution solution at rate $0.05 \mathrm{ml}_{\text {second }}{ }^{-1}$ and pressured gentle with plastic pestil. Filtrate from elution were drying by $\mathrm{N}_{2}$ gas and added $3 \mathrm{ml}$ distillated water and analyzing to obtained absorbance values at maximum wave length $(230 \mathrm{~nm})$. The graphic of the additional standard solution series vs. absorbance was using for calculation drug concentration on human blood plasma after plotted their absorbance values to the graph. The Vx0 equation was used for measurement of linearity at series 0,5 to $100 \mathrm{ppm}$. The $\mathrm{Vx} 0$ (Vervahrenvariationk oeffizient) equation was described at equation 1 with $\mathrm{Sx} 0$ (vervahrenstandardabweichung) and Sy (mean residual deviation of the function) refereed to equation $2 .^{14}$

Equation 1. $V \times 0=\frac{S \times 0}{X} \bullet 100 \%$

Equation 2, where $S y=\sqrt{\frac{\sum(Y i-\bar{i} i)^{2}}{N-2}}$ for $\mathrm{Yi}=\mathrm{a}+\mathrm{bXi}$ $S \times 0=\frac{S y}{b}$

In order to investigate accuracy and precision of the method the samples were spiked with standard solutions and then analyzed by the mentioned method at below. The accuracy expressed as percent recovery was obtained by comparing the results between the Phenazone found and the Phenazone standard. ${ }^{15}$ The precision expressed as percent coefficient variation was obtained by divided the values of standard deviation with the mean of concentration at five times replicates. ${ }^{16}$

\section{RESULT}

The result procedures at the first step was appeared good correlation at ranging of the mean concentrations 0.5 to $100 \mu$ g.ml $\mathrm{m}^{-1}$ ( $\mathrm{p}<0.05$, Table 1 , Figure 1$)$.

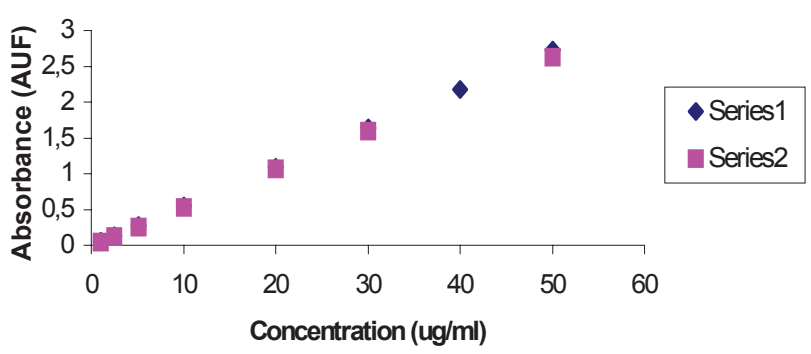

Figure 1. The linearity analysis of Phenazone dissolved in distillated water $(\diamond)$ at mean of 1.002 to 50.002 $\mu \mathrm{g} \cdot \mathrm{ml}^{-1}$ of 0,502 to $100 \mu \mathrm{g} \cdot \mathrm{ml}^{-1}$. The linearity analysis of Phenazone series at 1.002 to $50.002 \mu \mathrm{g} \cdot \mathrm{ml}^{-1}$ in human blood plasma (ם).

But the best purposed for additional standard was obtained at 1 to $50 \mu \mathrm{g} \cdot \mathrm{ml}^{-1}(\mathrm{CV}$ of absorbency $<5 \%$, Table 2 and Table 3 ). The $\mathrm{V} \times 0$ analysis of serial concentration (0.5-100 ppm) was not necessary linear (various) as referred to table 2 at below. The best serial concentration was obtained at $1.002 \mu \mathrm{g} \cdot \mathrm{ml}^{-1}$ to $50.001 \mu \mathrm{g} \cdot \mathrm{ml}^{-1}$. The result research of accuracy and precision of that procedures were

Table 1. The result analysis of linearity Phenazone in distillated water

\begin{tabular}{|c|c|c|c|c|c|c|c|c|c|c|c|}
\hline \multicolumn{6}{|c|}{ Concentration in $\mu \mathrm{g} \cdot \mathrm{ml}^{-1}$} & \multicolumn{5}{|c|}{ Absorbance $(\AA)$ in AUF } & \multirow{2}{*}{ Mean $\pm(\% \mathrm{CV})$} \\
\hline $\mathrm{n}-1$ & $\mathrm{n}-2$ & $n-3$ & $\mathrm{n}-4$ & $\mathrm{n}-5$ & Mean $\pm(\% \mathrm{CV})$ & $\mathrm{n}-1$ & $\mathrm{n}-2$ & $\mathrm{n}-3$ & $\mathrm{n}-4$ & $\mathrm{n}-5$ & \\
\hline 0.502 & 0.501 & 0.501 & 0.504 & 0.505 & $0.503 \pm 0.36$ & 0.002 & 0.003 & 0.002 & 0.003 & 0.002 & $0.002 \pm 22.83$ \\
\hline 1.002 & 1.002 & 1.003 & 1.002 & 1.002 & $1.002 \pm 0.045$ & 0.048 & 0.049 & 0.051 & 0.052 & 0.051 & $0.050 \pm 3.273$ \\
\hline 2.504 & 2.503 & 2.503 & 2.504 & 2.503 & $2.503 \pm 0.023$ & 0.136 & 0.137 & 0.136 & 0.137 & 0.135 & $0.136 \pm 0.615$ \\
\hline 5.103 & 5.102 & 5.103 & 5.102 & 5.102 & $5.102 \pm 0.022$ & 0.271 & 0.270 & 0.269 & 0.270 & 0.271 & $0.270 \pm 0.310$ \\
\hline 10.003 & 10.002 & 10.002 & 10.003 & 10.002 & $10.002 \pm 0.005$ & 0.545 & 0.546 & 0.544 & 0.545 & 0.543 & $0.545 \pm 0.209$ \\
\hline 20.002 & 20.002 & 20.001 & 20.002 & 20.002 & $20.002 \pm 0.002$ & 1.091 & 1.091 & 1.090 & 1.091 & 1.091 & $1.091 \pm 0.041$ \\
\hline 30.002 & 30.001 & 30.001 & 30.002 & 30.001 & $30.001 \pm 0.002$ & 1.638 & 1.637 & 1.638 & 1.637 & 1.638 & $1.638 \pm 0.033$ \\
\hline 40.001 & 40.001 & 40.001 & 40.002 & 40.001 & $40.001 \pm 0.001$ & 2.180 & 2.181 & 2.180 & 2.182 & 2.181 & $2.181 \pm 0.038$ \\
\hline 50.001 & 50.002 & 50.001 & 50.002 & 50.001 & $50.001 \pm 0.001$ & 2.728 & 2.729 & 2.726 & 2.727 & 2.726 & $2.727 \pm 0.048$ \\
\hline 60.001 & 60.001 & 60.001 & 59.999 & 60.002 & $60.001 \pm 0.002$ & 3.268 & 3.272 & 3.269 & 3.888 & 2.865 & $3.112 \pm 6.293$ \\
\hline 70.001 & 70.001 & 70.001 & 70.001 & 70.000 & $70.001 \pm 0.001$ & 3.789 & 3.798 & 3.811 & 2.989 & 3.790 & $3.635 \pm 9.945$ \\
\hline 80.000 & 80.001 & 80.000 & 80.000 & 80.002 & $80.001 \pm 0.001$ & 4.365 & 4.333 & 3.994 & 3.345 & 3.911 & $3.990 \pm 10.336$ \\
\hline 90.000 & 90.002 & 90.000 & 90.001 & 90.002 & $90.001 \pm 0.001$ & 4.911 & 4.912 & 4.231 & 3.881 & 4.001 & $4.387 \pm 11.280$ \\
\hline 100.000 & 100.001 & 100.002 & 100.001 & 100.000 & $100.000 \pm 0.001$ & 5.214 & 5.111 & 4.895 & 4.021 & 4.233 & $4.695 \pm 11.421$ \\
\hline
\end{tabular}


Table 2. The Linear analysis of Phenazone in distillated water

\begin{tabular}{|c|c|c|c|c|}
\hline $\begin{array}{l}\text { The mean of serial Conct. } \\
\qquad\left(\mu \mathrm{g} \cdot \mathrm{ml}^{-1}\right)\end{array}$ & $\begin{array}{c}\text { Sy } \\
\left(\mu \mathrm{g} \cdot \mathrm{ml}^{-1}\right)\end{array}$ & $\begin{array}{l}\text { Coefficient Correlation* } \\
\text { (r) }\end{array}$ & $\begin{array}{l}\mathrm{Vx} 0 * * \\
(\%)\end{array}$ & $\begin{array}{c}\mathrm{Xp} * * * \\
\left(\mu \mathrm{g} \cdot \mathrm{ml}^{-1}\right)\end{array}$ \\
\hline $0.503-100.00$ & 0.446 & $\begin{array}{l}0.971, \mathrm{p}<0.05 \\
\text { (Good) }\end{array}$ & $\begin{array}{c}22.431 \\
\text { (Not good) }\end{array}$ & $\begin{array}{c}33.534 \\
\text { (Not good) }\end{array}$ \\
\hline $0.503-90.001$ & 0.099 & $\begin{array}{l}0.998, \mathrm{p}<0.05 \\
\text { (Good) }\end{array}$ & $\begin{array}{c}5.585 \\
\text { (Not good) }\end{array}$ & $\begin{array}{c}7.622 \\
\text { (Not good) }\end{array}$ \\
\hline $0.503-80.001$ & 0.076 & $\begin{array}{l}0.999, \mathrm{p}<0.05 \\
\text { (Good) }\end{array}$ & $\begin{array}{c}4.841 \\
\text { (Moderate) }\end{array}$ & $\begin{array}{c}5.834 \\
\text { (Not good) }\end{array}$ \\
\hline 0.5 to 70.001 & 0.050 & $\begin{array}{l}0.999, \mathrm{p}<0.05 \\
\text { (Good) }\end{array}$ & $\begin{array}{c}3.627 \\
\text { (Moderate) }\end{array}$ & $\begin{array}{c}3.802 \\
\text { (Not good) }\end{array}$ \\
\hline 0.5 to 60.001 & 0.045 & $\begin{array}{l}0.999, \mathrm{p}<0.05 \\
\text { (Good) }\end{array}$ & 3.830 (Moderate) & $\begin{array}{c}3.412 \\
\text { (Not good) }\end{array}$ \\
\hline 0.5 to 50.001 & 0.008 & $\begin{array}{l}0.999, \mathrm{p}<0.05 \\
\text { (Good) }\end{array}$ & $\begin{array}{c}0.809 \\
\text { (Good) }\end{array}$ & $\begin{array}{c}0.599 \\
\text { (Not good) }\end{array}$ \\
\hline 0.5 to 40.001 & 0.008 & $\begin{array}{l}0.999, \mathrm{p}<0.05 \\
\text { (Good) }\end{array}$ & $\begin{array}{l}1.102 \\
\text { (Good) }\end{array}$ & $\begin{array}{c}0.650 \\
\text { (Not good) }\end{array}$ \\
\hline 0.5 to 30.001 & 0.008 & $\begin{array}{l}0.999, \mathrm{p}<0.05 \\
\text { (Good) }\end{array}$ & $\begin{array}{l}1.579 \\
\text { (Good) }\end{array}$ & $\begin{array}{c}0.706 \\
\text { (Not good) }\end{array}$ \\
\hline $1.002-100.00$ & 0.132 & $\begin{array}{l}0.997, \mathrm{p}<0.05 \\
\quad \text { (Good) }\end{array}$ & $\begin{array}{c}6.372 \\
\text { (Not good) }\end{array}$ & $\begin{array}{c}10.656 \\
\text { (Not good) }\end{array}$ \\
\hline $1.002-90.001$ & 0.100 & $\begin{array}{l}0.998, \mathrm{p}<0.05 \\
\text { (Good) }\end{array}$ & $\begin{array}{c}5.241 \\
\text { (Not good) }\end{array}$ & $\begin{array}{c}7.917 \\
\text { (Not good) }\end{array}$ \\
\hline $1.002-80.001$ & 0.077 & $\begin{array}{l}0.999, \mathrm{p}<0.05 \\
\text { (Good) }\end{array}$ & $\begin{array}{c}4.528 \\
\text { (Moderate) }\end{array}$ & $\begin{array}{c}6.107 \\
\text { (Not good) }\end{array}$ \\
\hline $1.002-70.001$ & 0.051 & $\begin{array}{l}0.999, \mathrm{p}<0.05 \\
\text { (Good) }\end{array}$ & $\begin{array}{c}3.355 \\
\text { (Moderate) }\end{array}$ & $\begin{array}{c}3.989 \\
\text { (Not good) }\end{array}$ \\
\hline $1.002-60.001$ & 0.046 & $\begin{array}{c}0.999, \mathrm{p}<0.05 \\
\quad(\text { Good })\end{array}$ & $\begin{array}{c}3.557 \\
\text { (Moderate) }\end{array}$ & $\begin{array}{c}3.651 \\
\text { (Not good) }\end{array}$ \\
\hline $1.002-50.001$ & 0.003 & $\begin{array}{l}0.999, \mathrm{p}<0.05 \\
\text { (Good) }\end{array}$ & $\begin{array}{l}0.272 \\
\text { (Good) }\end{array}$ & $\begin{array}{c}0.238 \\
\text { (Good) }\end{array}$ \\
\hline
\end{tabular}

Table 3. Analysis of accuracy and precision of procedure determination of Phenazone in human blood plasma

\begin{tabular}{|c|c|c|c|c|c|c|c|c|c|c|c|c|}
\hline \multirow{2}{*}{\multicolumn{2}{|c|}{$\begin{array}{c}\text { Phenazone in } \\
\text { distillated water }\end{array}$}} & \multicolumn{10}{|c|}{ Absorbance $(\AA)$ Phenazone in blood plasma (AUF) } & \multirow{3}{*}{$\begin{array}{l}\text { Intraday } \\
\text { precision } \\
(\% \mathrm{CV})\end{array}$} \\
\hline & & \multicolumn{2}{|c|}{ Replication-1 } & \multicolumn{2}{|c|}{ Replication-2 } & \multicolumn{2}{|c|}{ Replication-3 } & \multicolumn{2}{|c|}{ Replication-4 } & \multicolumn{2}{|c|}{ Replication-5 } & \\
\hline $\begin{array}{c}\text { Drug conc. } \\
\left(\mu \mathrm{g} \cdot \mathrm{ml}^{-1}\right)\end{array}$ & $\begin{array}{c}\text { Absorbance } \\
\text { (AUF) }\end{array}$ & $\begin{array}{l}(\AA) \\
\text { AUF }\end{array}$ & $\begin{array}{c}\text { Recovery } \\
\%\end{array}$ & $\begin{array}{l}(\AA) \\
\text { AUF }\end{array}$ & $\begin{array}{c}\text { Recovery } \\
\%\end{array}$ & $\begin{array}{l}(\AA) \\
\text { AUF }\end{array}$ & $\begin{array}{c}\text { Recovery } \\
\%\end{array}$ & $\begin{array}{l}(\AA) \\
\text { AUF }\end{array}$ & $\begin{array}{c}\text { Recovery } \\
\%\end{array}$ & $\begin{array}{l}(\AA) \\
\text { AUF }\end{array}$ & $\begin{array}{c}\text { Recovery } \\
\%\end{array}$ & \\
\hline 1.002 & 0.050 & 0.043 & 86.000 & 0.047 & 94.000 & 0.041 & 82.000 & 0.042 & 84.000 & 0.046 & 92.000 & 5.913 \\
\hline 2.503 & 0.136 & 0.127 & 92.029 & 0.125 & 91.912 & 0.123 & 90.441 & 0.128 & 94.118 & 0.126 & 92.647 & 1.508 \\
\hline 5.102 & 0.270 & 0.259 & 95.926 & 0.257 & 95.185 & 0.255 & 94.444 & 0.258 & 95.555 & 0.256 & 94.815 & 0.615 \\
\hline 10.002 & 0.545 & 0.528 & 96.887 & 0.527 & 96.697 & 0.525 & 96.330 & 0.524 & 96.147 & 0.521 & 95.596 & 0.522 \\
\hline 20.002 & 1.091 & 1.067 & 97.800 & 1.066 & 97.708 & 1.063 & 97.433 & 1.061 & 97.250 & 1.062 & 97.342 & 0.243 \\
\hline 30.012 & 1.638 & 1.601 & 97.741 & 1.600 & 97.680 & 1.597 & 97.497 & 1.598 & 97.558 & 1.596 & 97.436 & 0.116 \\
\hline 50.002 & 2.727 & 2.616 & 95.929 & 2.618 & 96.003 & 2.620 & 96.076 & 2.622 & 96.150 & 2.630 & 96.443 & 0.206 \\
\hline \multicolumn{2}{|c|}{$\begin{array}{c}\text { Recovery } \\
(\text { mean } \pm \% \mathrm{CV}) \\
\end{array}$} & \multicolumn{2}{|c|}{$94.616 \pm 4.514$} & \multicolumn{2}{|c|}{$95.598 \pm 2.197$} & \multicolumn{2}{|c|}{$93.460 \pm 5.998$} & \multicolumn{2}{|c|}{$94.397 \pm 5.002$} & \multicolumn{2}{|c|}{$95.183 \pm 2.278$} & 0.862 \\
\hline
\end{tabular}


apparently good at mean 94.651 percent of recoveries and 0.862 percent of coefficient variation as illustrated at Table 3 .

\section{DISCUSSION}

The method described here is based partly on the method development by Nuraini et al., ${ }^{8}$ but by pressuring of SPE during the elution process, It was make a good recovery in determination of Phenazone in human blood plasma. ${ }^{17}$

Our recovery was apparently 1.5 to $3 \%$ highest than Nuraini et al., ${ }^{8}$ method at ranging 93.460 to $95.598 \%$. The bias of precision described here was shown lowest than their protocol, although we saw both of them still satisfaction (The $\mathrm{CV}<2 \%$ ).

Each step in the assay method has been examined to give optimal results, provided the following precautions are observed. Separation by SPE should be carried out at room temperature by methanol: glacial acetic acid $0.5 \%(\mathrm{v} / \mathrm{v})$ dissolve in distillated water $2: 80$ for at least $0.05 \mathrm{ml}$. second $^{-1}$ rate pressure to ensure complete separation of Phenazone. After drying by $\mathrm{N}_{2}$, all samples must be added by distillated water not more than 15 minutes. That process was doing to kept the chance of $\mathrm{pH}$ solution from acid to basic condition. The wavelength of $230 \mathrm{~nm}$ will be maximum detecting to aqueous sample in acid condition (5 to $6 \mathrm{pH}$ solution) at not more than 2 hours. ${ }^{4,8}$ Accurate timing and adequate mixing between the addition of each reagent is essential. If these precautions are taken, then reproducibility between experiments is $2 \%$, and it is possible to determine accurately of $1 \mu \mathrm{g} \cdot \mathrm{ml}^{-1}$ to $50 \mu \mathrm{g} \cdot \mathrm{ml}^{-1}$ samples (Figure 1). The sensitivity of the method is limited at least 1 to $50 \mu \mathrm{g} \cdot \mathrm{ml}^{-1}$ sample concentration, because of a decrease in the yield of Phenazone during the sample preparation especially in $\mathrm{pH}$ factor.

Our method could be of use in monitoring drug concentrations in human undergoing treatment of Phenazone. Phenazone as an analgesic and anti-inflammatory purposed or for dentistry cases was available effective in human blood bodies at about $250 \mu \mathrm{g} \cdot \mathrm{ml}^{-1}$ to $500 \mu \mathrm{g} \cdot \mathrm{ml}^{-1}$. That ranging concentration at above can be monitored by our procedures after diluted 10 times for reduced their concentration up to $50 \mu \mathrm{g} \cdot \mathrm{ml}^{-1}$ as mentioned at additional standard procedure (Table 1).

These procedures could be of use for monitored therapeutics of Phenazone for obtained suitable drug level at ranging 1 to $50 \mu \mathrm{g} \cdot \mathrm{ml}^{-1}$. At 1 to $50 \mu \mathrm{g} \cdot \mathrm{ml}^{-1}$ of Phenazone have small deviation values of accuracy-precise and also still remain on the right tract of the recommended values of accuracy $(80-120 \%)$ and precise $(<10-20 \%)$. Recommended of this research was follows; at more than $50 \mu \mathrm{g} \cdot \mathrm{ml}^{-1}$, the series concentrations must be diluted to 10 times or 100 times. The monitored therapeutic activities may be important contributors to the re-arrangement regimentation dosage, especially for dentistry in children cases or elderly cases.

\section{ACKNOWLEDGEMENT}

This work is following research of Nuraini Farida, MS., Pharm, Bambang Hermanto dr., MS and Lazuardi M, PhD., MSc., DVM at MRU research project 2005/2006. Sponsorship: MRU Medical Faculty Airlangga University. The author would like to thank Dean of Medical Faculty Airlangga University as sponsorship of this research by Medical Research Unit, Medical Faculty Airlangga University at program 2005/2006.

\section{REFERENCES}

1. Kenakin TP, editor. A pharmacology primer: Theory, application and methods. $2^{\text {nd }}$ ed. California, USA: Academic Press; 2006. p. 200-5.

2. Reynolds FEF, editor. Martindale: The extract pharmacopoeia (Reference Material). London: The Pharmaceutical Press; 2004. p. 28-29.

3. Mitič SS, Živanovič VV. A kinetic method for the determination of phenol. J Serb Chem Soc 2002; 67(10):661-7.

4. Moffat AC, Osselton MD, Widdop B, editor. Clarke's analysis of drugs and poisons. Vol 2. 1 Lambert High Street, London, UK: The Pharmaceutical Press (PhP); 2004. p. 555-8.

5. Palette C, Cordomier P, Naline E, Advenier C, Pays M. HighPerformance Liquid Chromatographic method for determination of the three main oxidative and 3-carboxylic antipyrine metabolites in human urine. J Chromatogr 1992; 563:103-13.

6. Mikati Ma, Szabo GK, Pylilo RJ. Improved High-Performance Liquid Chromatographic assay of Antipyrine, Hydroxymethyl antipyrine and norantipiryne in urine. J Chromatogr 1988; 433:305-11.

7. Danhof M, De-Groot-Van Der Vis E, Breimer DD. Assay of Antipyrine and its primary metabolites in plasma, saliva and urine by High Performance Liquid Chromatography and some preliminary results in man. Pharmacology 1979; 18:210-23.

8. Nuraini F, Bambang H, Lazuardi M. The determination of antipyrine in plasma by Spectrophotometer UV-Vis. Surabaya: Research Report Medical Research Unit, Medical Faculty Airlangga University, 2006 September. p. 5-20.

9. Supelco Chromatography. Chromatography (Product for analysis and purification). Singapore (South Asia Region): Sigma-Aldrich 2001; p. 257-97.

10. Nuraini F, Lazuardi M, Ratna SM. The Determination of Trypamidium in blood plasma by spectrophotometer UV-Vis. Medika Eksakta 2001; 2(2):92-8.

11. Lazuardi M. The Determination of Sulfamethazine in blood plasma by Spectrophotometer UV-Vis. In: Aulanni'am, editor. Basic science workshop mathematic and natural science Brawijaya University, 2006 February 16-18, Malang, Jawa Timur; 2006. p. 19.

12. Eichllbaum M, Somntag B, Dengler HJ. HPLC Determination of antipyrine metabolites. Pharmacology 1981; 23:192-02.

13. Akira K, Negishi E, Sakuma C, Hashimoto T. Direct detection of antipyrine metabolits in rat urine by $13 \mathrm{c}$ Labeling and NMR Spectroscopy. Drug Metabolism and Disposition 1999; 27(1): 1248-53.

14. Funk W, Dammann V, Donnevert G. Qualitätsicherung in der analytischen chemie. London, New York: VCH; 1992. p. 8-200.

15. Ellison SLR, King B, Rösslein M, William A, editors. Eurachem/ CITAC Guide: Quantifying Uncertainty in Analytical Measurement. $2^{\text {nd }}$ ed. UK: EURACHEM/CITAC/AOAC/IAEA/EA Working Groups; 2000. p. 4-120.

16. Lazuardi M. A rapid isocratic HPLC assay of diminazene aceturatein blood plasma. Jurnal Kedokteran YARSI 2005; 13(3):298-05

17. AOAC-International. Volume I: Official Method of Analysis of AOAC International. (Agriculture; Chemicals; Contaminants Drugs). $17^{\text {th }}$ eds. USA: The Scientific Association AOAC International Press; 2002. p. 29-30. 